\title{
FIGUR AYAH PENDIDIK DI DALAM AL-QUR'AN DAN HADIS
}

\author{
Wagiman Manik \\ Program Studi Pendidikan Bahasa Arab STAI As-Sunnah \\ Jl. Medan-Tj. Morawa, KM 13, Gg. Darmo, Desa Bangun Sari, Kab. D. Serdang, Sumut
}

\begin{abstract}
Abstrak Figur ayah terhadap keluarga sangatlah penting. Karena ayah adalah kepala keluarga. Ayah juga sangat memiliki andil besar dalam mendidik anakanaknya, karena dengan dirinya anak dapat belajar bagaimana bisa menjadi orang yang berkompeten dalam bekerja dan mencari rezeki bagi keluarganya. Di dalam Alquran terdapat banyak ayat yang menjelaskan bagaimana dialog seorang ayah dengan anaknya, dari pada ayat yang menjelaskan dialog seorang ibu berdialog dengan anaknya.dari situ sudah tampak jelas bagaimana peran ayah bagi seorang anak.

Seorang anak sangat membutuhkan kehadiran ayah, sebagaimana pula dia begitu ingin dekat dan dicintai oleh ibunya. Seorang ayah yang super sibuk dan menyerahkan segala tanggung jawab pendidikan anaknya kepada istrinya tanpa ada upaya untuk terlibat di dalam membimbing anaknya, ia bukanlah figur orang tua yang baik.

Memang urusan domestik rumah tangga termasuk bagaimana mendampingi mereka belajar, mengembangkan kreativitas, membentuk kepribadian dan karakter, curhat dan juga segala hal yang berkaitan dengan kebutuhan fisik, materi, emosional, sosial, bahkan pembiasaan-pembiasaan yang berhubungan dengan keimanan, akhlak atau ibadah biasanya ditangani seorang istri. Ibaratnya wanita sebagai manager $R T$.
\end{abstract}

Kata Kunci: Figur, Ayah, Pendidik, Al-Qur'an, Hadis

\section{A. Mengenal Ayah}

\section{Mengenal Singkat Tentang Ayah}

Sosok ayah penuh cinta dan dicintai anaknya! rasanya semua pria ingin menjadi ayah yang selalu dirindukan anaknya. Ayah yang lembut tidak kasar namun tetepa disegani anak-anak. "Sungguh tidaklah sifat lemah lembut ada pada sesuatu melainkan ia menghiasinya. Dan tidaklah sifat lemah lembut tercabut dari sesuatu melainkan ia menjadikannya buruk. (Hr. Muslim no. 6767).

Salah satu kunci pembuka untuk akrab dan dekat dengan anak adalah sifat lembut. Orang tua yang membiasakan kelembutan dalam mendidik anak, maka anak in syaa Allah akan bertutur kata lembut, bersikap hati-hati dan tidak berperangai keras lagi kasar. Rasulullah saw telah mencontohkan kepada kita bagaimana bergaul dan berinteraksi dengan anak kecil yang didasari rasa kasih sayang yang tulus. Anas menegaskan: "Rasulullah adalah yang paling penyayang 
terhadap anak dan keluarga". (hadits shohih riwayat Ibnu Asakir, shohih al-jami' no. 40). Ibnu Abbas menuturkan, "Rasulullah saw mengunjungi kaum anshar lalu memberi salam kepada anak-anak mereka, serta membelai kepala mereka."(HR. an-Nasai dishahihkan al-Albani dalam shahih al-Jami’ no. 4947).

Kedekatan beliau dengan anak-anak tidak menghalangi untuk menyampaikan nasihat dan bimbingan ketika anak-anak melakukan kesalahan. Umar bin Abi salamah bercerita, "dulu aku adalah bocah yang berada dalam pengasuhan Rasulullah saw", suatu ketika tangan ku berseliweran diatas nampan, maka Rasulullah saw bersabda kepadaku,

$$
\text { يا غلام سم الله وكل بيمينك وكل مما يليك }
$$

Ananda bacalah bismillah dan makanlah dengan tangan kananmu dan apa yang ada disekitarmu." (HR. Bukhari dan Muslim)

Sangat indah gambaran islam tentang kasih sayang seorang ayah yang tulus kepada anaknya. Ayah ialah seorang yang termasuk memiliki peran penting didalam pendidikan seorang anak, selain sebagai kepala keluarga yang berkewajiban mencari nafkah, pendidika anak juga termasuk bagian dari tanggung jawab seorang ayah, lantas bagaimana figur seorang ayah dalam pendidik anak? Hal ini sudah dijelaskan didalam alquran tentunya dan yang paling masyhur tentang seorang ayah sebagai pendidik adalah kisah didalam surat luqman yang menceritakan bagaimana peran ayah ketika menjadi seorang pendidik.

\section{Defenisi Pendidik Dalam Pendidikan Islam}

Dalam kamus bahasa Indonesia kata pendidik adalah berarti orang yang mendidik. ${ }^{1}$ Dalam bahsaa inggris ditemukan kata teacher yang berarti pengajar. Selain itu terdapat kata turor yang berarti pengajar pribadi yang mengajar di rumah, mengajar ekstra, member les tambahan pembelajaran, educator, ${ }^{2}$ ahli didik, lecturer, dan penceramah.

Para pakar oendidikan dalam pendidikan islam, menggunakan rumusan yang berbeda-beda tentang pendidik. Zakiyah drajat misalnya, dia berpendapat bahwa pendidik adalah individu yang akan memenuhi kebutuhan pengetahuan,

\footnotetext{
${ }^{1}$ Tim penyusun Kamus Besar Bahasa Indonesia (Jakarta: Balai pustaka, 2005), h.263.

2 Jhon M. Echols dan hasan shdily, kamus Indonesia inggris (Jakarta: PT. Gramedia, 1992) h. 144.
} 
sikap dan tingkah laku pendidik.3 Sedangkan ahmad tafsir mengartikan pendidik dalam islam adalah orang-orang yang bertanggung jawab terhadap perkembangan peserta didiknya, yaitu dengan upayah mengembangkan seluruh potensi peserta dididk, baik potensi psikomotorik, kognitif, maupun afektif. ${ }^{4}$

Bercerita tentang peran ayah sebagai pendidik tentunya sudah digambarkan oleh luqman yang allah abadikan kisahnya dalam alquran. QS. Luqman adalah surat ke-31 yang terdiri dari 34 ayat yang diturunkan di makkah. Alquran tidak menerangkan asal-usul luqman, tetapi yang penting adalah kebijaksanaan yang diwariskan kepada pitra-putranya, yang memiliki keilmuan yang begitu tinggi, sehingga mereka dicatat sebagai ayat-ayat di alquran, disebutkan dua kali yaitu dalam ayat 12 dan 13. Keinginan luqman untuk putranya hanya terdiri dari 7 ayat. Tetapi dalam ayat ketujuh dasar-dasar pendidikan penting bagi seorang ayah, yang tidak akan berubah selama manusia masih hidup didunia ini. Adapun penggalan ayat dari surat Luqman adalah sebagai berikut:

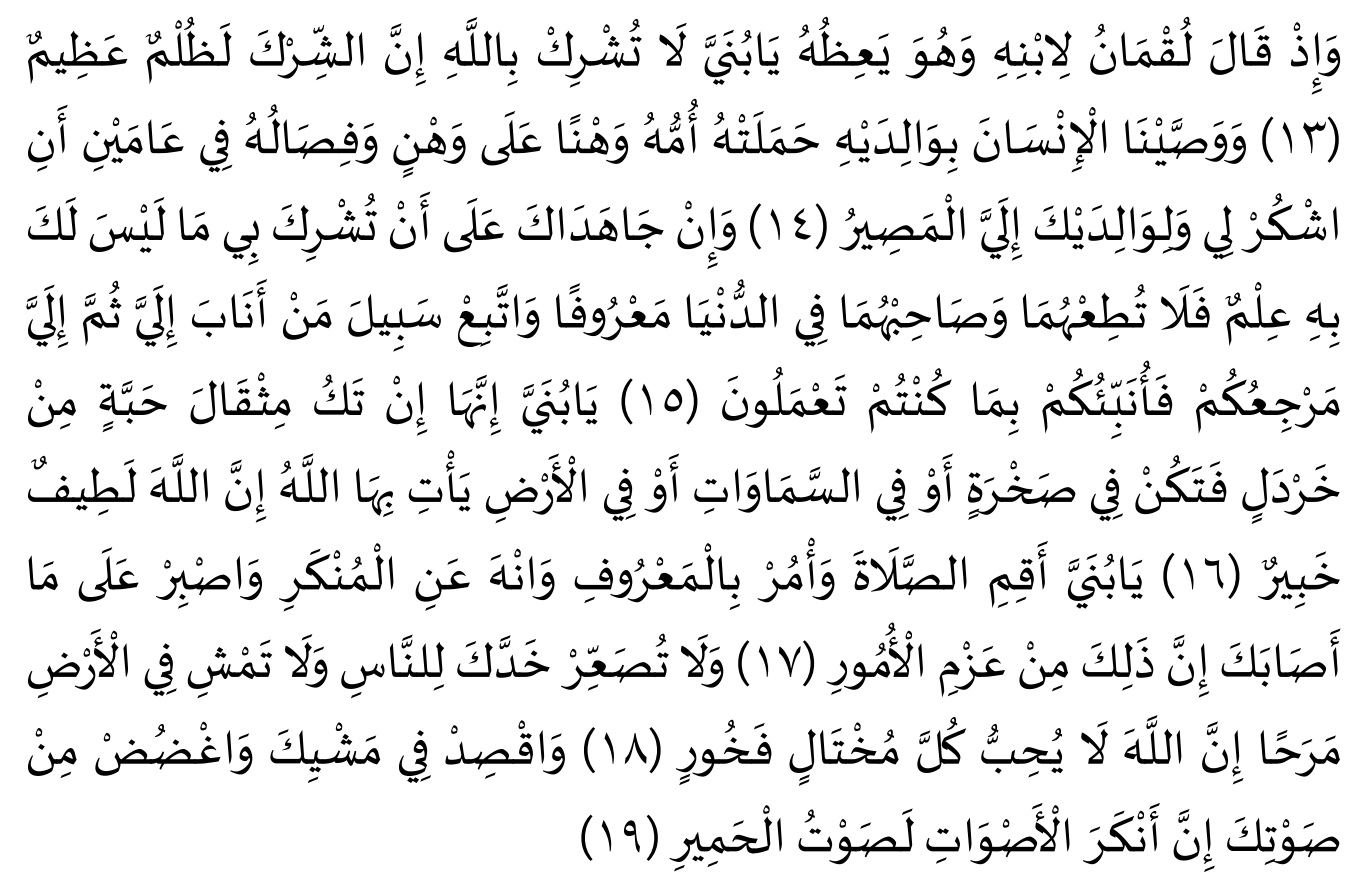

Dan (ingatlah) ketika Luqman berkata kepada anaknya, di waktu ia memberi pelajaran kepadanya: "Hai anakku, janganlah kamu mempersekutukan Allah, sesungguhnya mempersekutukan (Allah) adalah benar-benar kezaliman yang besar". Dan Kami perintahkan kepada manusia (berbuat baik) kepada dua orang ibu-bapaknya; ibunya telah mengandungnya dalam keadaan lemah

${ }^{3}$ Zakiyah Drajat, Islam untuk Disiplin ilmu pendidikan (Jakarta: Bulan Bintang,1987), h. 19.

${ }^{4}$ Ahmad Tafsir, Ilmu Pendidikan dalam Persfektif Islam (Bandung: Remaja Rosdakarya: 1992), h.74. 
yang bertambah-tambah, dan menyapihnya dalam dua tahun. Bersyukurlah kepada-Ku dan kepada dua orang ibu bapakmu, hanya kepada-Kulah kembalimu. Dan jika keduanya memaksamu untuk mempersekutukan dengan Aku sesuatu yang tidak ada pengetahuanmu tentang itu, maka janganlah kamu mengikuti keduanya, dan pergaulilah keduanya di dunia dengan baik, dan ikutilah jalan orang yang kembali kepada-Ku, kemudian hanya kepadaKulah kembalimu, maka Kuberitakan kepadamu apa yang telah kamu kerjakan. (Luqman berkata): "Hai anakku, sesungguhnya jika ada (sesuatu perbu atan) seberat biji sawi, dan berada dalam batu atau di langit atau di dalam bumi, niscaya Allah akan mendatangkannya (membalasinya). Sesungguhnya Allah Maha Halus lagi Maha Mengetahui. Hai anakku, dirikanlah shalat dan suruhlah (manusia) mengerjakan yang baik dan cegahlah (mereka) dari perbuatan yang mungkar dan bersabarlah terhadap apa yang menimpa kamu. Sesungguhnya yang demikian itu termasuk hal-hal yang diwajibkan (oleh Allah). Dan janganlah kamu memalingkan mukamu dari manusia (karena sombong) dan janganlah kamu berjalan di muka bumi dengan angkuh. Sesungguhnya Allah tidak menyukai orang-orang yang sombong lagi membanggakan diri. Dan sederhanalah kamu dalam berjalan dan lunakkanlah suaramu. Sesungguhnya seburuk-buruk suara ialah suara keledai"

\section{Karesteristik Pendidikan yang terdapat dalam QS. Luqman}

Berdasrakn Alquran QS luqman terdapat Lima karasteristik Luqman hakim dalam mendidik anak. Adapu lima poin tersebut adalah:

\section{a. Pendidikan Akidah}

Secara sederhana pendidikan tauhid mempunyai arti suatu proses bimbingan, untuk mengembangkan dan memantapkan kemampuan manusia dalam mengenal keesaan Allah swt. Pendidikan tauhid yang berarti membimbing atau mengembangkan potensi (fitrah) manusia dalam mengenal Allah swt. ini, menurut pendapat Chabib Thoha, "supaya anak dapat memiliki dan meningkatkan terus menerus nilai iman dan taqwa kepada Allah Yang Maha Esa sehingga pemilikan dan peningkatan nilai tersebut dapat menjiwai tumbuhnya nilai kemanusiaan yang luhur.

Akidah dalam Islam meliputi keyakinan dalam hati mengenai Allah swt. sebagai satu-satunya Tuhan yang harus di sembah, perkataan dengan lisan dalam bentuk dua kalimat syahadat, yakni menyatakan bahwa tidak ada Tuhan selain Allah serta Nabi Muhammad Saw. sebagai utusan-Nya. Akidah yang demikian mengandung pengertian bahwa pada seseorang yang beriman, tidak ada rasa

5 Kementrian Agama RI, Al-Qur'an dan Tafsirnya. Edisi yang disempurnakan (Jakarta: Lentera Abadi, 2010), jilid VIII, h. 230. 
dalam hati ataupun ucapan di mulut serta perbuatan, melainkan menggambarkan iman terhadap Allah, artinya tidak ada niat, ucapan, dan perbuatan yang di lakukan oleh seorang beriman itu, kecuali satu jalan dengan kehendak Allah.

\section{b. Pendidikan Akhlak Terhadap Orang Tua}

Akhlak merupakan buah Islam yang bermanfaat bagi kehidupan manusia dan membuat hidup menjadi lebih baik. Akhlak merupakan alat kontrol psihis dan sosial bagi individu dan masyarakat. Tanpa akhlak, manusia tidak akan berbeda dari kumpulan binatang ${ }^{6}$. Diantara akhlak yang perlu ditanamkan seorang ayah kepada anak adalah tentang akhlak kepada orang tua atau Birr al-Wālidayn. Seperti yang terdapat didalam surat Luqman ayat 14.

Dan Kami perintahkan kepada manusia (berbuat baik) kepada dua orang ibubapaknya; ibunya telah mengandungnya dalam keadaan lemah yang bertambahtambah, dan menyapihnya dalam dua tahun. Bersyukurlah kepada-Ku dan kepada dua orang ibu bapakmu, hanya kepada-Kulah kembalimu”

\section{c. Pendidikan Intelektual}

Luqman berkata: "Hai anakku, sesungguhnya jika ada (sesuatu perbuatan) seberat biji sawi, dan berada dalam batu atau di langit atau di dalam bumi, niscaya Allah akan mendatangkannya (membalasinya). Sesungguhnya Allah Maha Halus lagi Maha Mengetahui”

Pendidikan intelektual ini masih berhubungan dengan pendidikan tauhid, tanpa tauhid yang sempurna seseorang tidak akan mengetahui bahwa setiap perkara pasti akan dipertanggung jawabkan oleh Allah swt. diakhirat kelak

\section{d. Pendidikan Ibadah}

Dalam QS. Luqman ayat 17 dijelaskan bahwa Luqman memerintahkan anaknya untuk melaksanakan sholat:

"Hai anakku, dirikanlah shalat dan suruhlah (manusia) mengerjakan yang baik dan cegahlah (mereka) dari perbuatan yang mungkar dan bersabarlah terhadap apa yang menimpa kamu. Sesungguhnya yang demikian itu termasuk hal-hal yang diwajibkan (oleh Allah swt.)"

Ibadah merupakan salah satu aspek penting dalam islam, tujuan utama dari di ciptakannya jin dan manusia adalah untuk beribadah kepada Allah swt. Semua ibadah yang ada dalam Islam bertujuan membawa individu ingat akan tuhan-Nya, dan selalu dekat dengan-Nya. Oleh karena itu, penanaman akan pentingnya ibadah untuk dilakukan, hendaknya di mulai sejak dini. Karena setiap perbuatan yang dilakukan manusia akan menjadi ibadah manakala perbuatan itu

${ }^{6}$ Hery Noer Aly, Dan H. Munzier S, MA. Watak Pendidikan Islam (Jakarta: Friska Agung Insani, 2003), h. 89. 
dilakukan dengan dasar ilmu dan juga keikhlasan yang tinggi dari si pelaku ibadah. Sehingga akan memperoleh balasan dari Allah swt. Sekalipun perbutan atau amal itu hanya sebesar biji sawi. Setiap orang yang melakukan sholat akan dapat merasakan ketenangan dan ketenteraman dalam batinnya, begitu pun perbuatannya senantiasa terjaga dari perbuatan keji dan mungkar.

\section{Kisah para ayah dalam alquran dalam mendidik anak}

\section{a. Ibrahim}

Kisah Ibrahim sebagai seorang ayah terdapat dalam surat ash Shafat ayat 100-102:

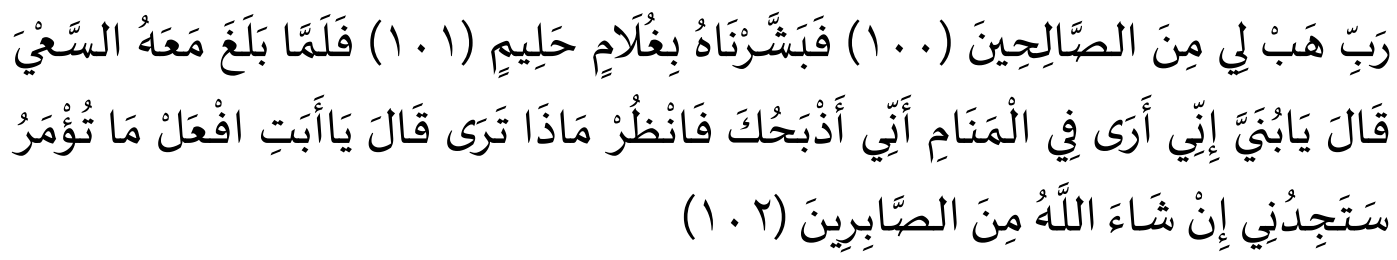

Ya Tuhanku, anugerahkanlah kepadaku (seorang anak) yang termasuk orang yang saleh. Maka Kami beri dia khabar gembira dengan seorang anak yang amat sabar. Maka tatkala anak itu sampai (pada umur) sanggup berusaha bersama-sama Ibrahim, Ibrahim berkata: "Hai anakku, sesungguhnya aku melihat dalam mimpi bahwa aku menyembelihmu. Maka pikirkanlah apa pendapatmu!" ia menjawab: "Hai bapakku, kerjakanlah apa yang diperintahkan kepadamu; insya Allah kamu akan mendapatiku termasuk orang-orang yang sabar". 7 ayah:

Terdapat pelajaran yang bisa diambil dari peran Ibrahim sebagai seorang

a. Ibrahim adalah seorang ayah yang penuh kasih sayang kepada anaknya. Dia memanggil anaknya dengan "ya bunayya", yang menggambarkan kemungilan. Pemungilan tersebut mengisyaratkan kasih sayang dan kemesraan. Ibrahim adalah seorang ayah yang demokratis, bukan otoriter. Meskipun Ibrahim meyakini behwa perintah menyembelih anaknya itu mesti dilaksanakan, akan tetapi Ibrahim tetap meminta pendapat anaknya, "Maka pikiranlah apa pendapatmu!"

b. Ibrahim adalah seorang ayah yang bersedia meluangkan waktu untuk berkomunikasi dengan anaknya. Ia tidak melaksanakan mimpinya dengan paksa hingga cepat selesai. Komunikasi dialogis kemungkinan akan memakan waktu yang lebih lama sampai anak menerima perintah

${ }^{7}$ Rahmi / Kafa'ah: Jurnal Ilmiah Kajian Gender Vol.V No.2 Tahun 2015. 
dengan penuh kesadaran. Ibrahim menghendaki anaknya menerima hal itu dalam ketaatan dan penyerahan diri, tidak dengan paksaan. Sehingga anaknya itupun mendapat pahala dan kelezatan ketaatan.

c. Ibrahim adalah seorang ayah yang menikmati masa-masa Bersama anaknya sebagaimana yang diisyaratkan kalimat "Maka ketika anak itu sampai (pada umur) sanggup berusahabersamanya". Menurut Hamka keadaan ini ditonjolkan dalam ayat ini untuk menunjukkan betapa tertumpahnya kasih sayang Ibrahim kepada anaknya itu, merasa bangga dan menikmati jika dapat berjalan dan menghabiskan waktu bersama-sama dengan anak. kalimat itu berarti Ibrahim merasakan kenikmatan terhadap anaknya, menyertai perjalanannya dan menemaninya dalam kehidupannya.

d. Ibrahim adalah seorang ayah yang mengajarkan dan memberi keteladanan kepada anaknya, terutama tentang kepasrahan ketaatan, dan kesempurnaan cinta kepada Allah. Ibrahim mematuhi perintah Allah untuk menyembelih anak remajanya, padahal sebelumnya Ibrahim menantikan kelahiran anak tersebut selama bertahun-tahun. Surat al Baqarah ayat 131-132 mengungkapkan nasehat Ibrahim kepada anakanaknya untuk tidak meninggalkan kepasrahan kepada Allah :
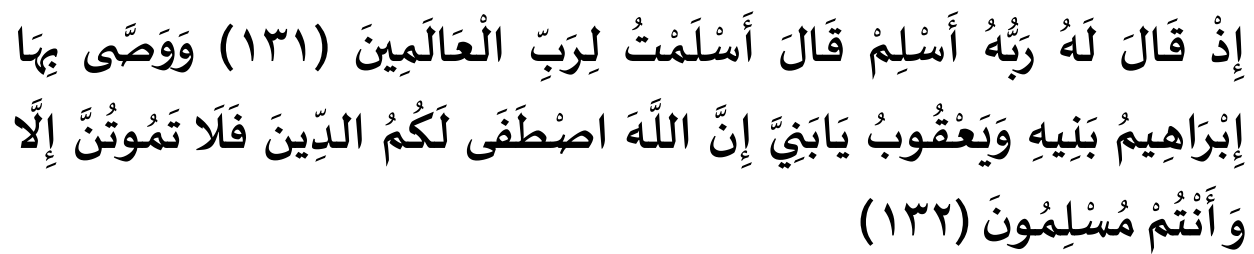

Ketika Tuhannya berfirman kepadanya: "Tunduk patuhlah! Ibrahim menjawab: "Aku tunduk patuh kepada Tuhan semesta alam". Dan Ibrahim telah mewasiatkan ucapan itu kepada anak-anaknya, demikian pula Ya'qub. (Ibrahim berkata): "Ha anak-anakku! Sesungguhnya Allah telah memilih agama ini bagimu, maka janganlah kamu mati kecuali dalam memeluk agama Islam".

Doa-doa Nabi Ibrahim memiliki peran penting dalam Pendidikan anaknya. Setiap berdoa untuk dirinya, Ibrahim selalu meminta anak keturunannya juga mendapatkan hal yang sama dengan dirinya. Tidak hanya satu doa Ibrahim untuk anaknya yang tercatat dalam al-Quran. Surat Ibrahim memuat beberapa doa Ibrahim untuk anak danketurunannya, antara lain:

1) mohon dijauhkan dari syirik (14:35) 
2) menjadi orang yang mendirikan shalat, disenangi orang, diberi rizki dan bersyukur (14: 37)

3) menjadi orang yang mendirikan shalat (14:40).

Dalam surat $\mathrm{Al}$ Baqarah juga terdapat doa Ibrahim kepada anak keturunannnya, antara lain:

1) menjadi pemimpin di dunia $(2: 124)$.

2) menjadi umat yang muslim berserah diri (2:128).

Melalui doa kepada Allah swt., Ibrahim merencanakan masa depan anaknya tidak hanya di dunia saja, tetapi juga masa depan yang sesungguhnya, yaitu akhirat. Tidak hanya untuk anaknya, kehidupan yang baik di dunia akhirat diinginkan, tetapi juga untuk cucu dan generasi selanjutnya. ${ }^{8}$

\section{b. Nabi Ya'kub}

Peran Nabi Ya'kub sebagai ayah diuraikan dalam surat Yusuf. Ya'kub merupakan sosok ayah yang sangat lengkap ceritanya dalam alQur'an. Satu surat dalam al-Qur'an, surat Yusuf, menguraikan interaksi Ya'kub dengan anak-anaknya. Surat ini menceritakan anak Ya'kub, Yusuf, telah bermimpi melihat sebelas bintang, matahari dan bulan sujud kepadanya. Yusuf menceritakan mimpinya tersebut kepada ayahya dan dia meminta Yusuf tidak menceritakan mimpinya tersebut kepada saudara-saudaranya.

Saudara-saudara Yusuf merasa Ya'kub lebih menyayangi Yusuf daripada mereka, oleh karena itu mereka berencana menyingkirkan Yusuf. Mereka meminta izin kepada Ya'kub untuk membawa Yusuf bermain dan ketika itu lah mereka sepakat memasukkan Yusuf ke dalam sumur. Ketika pulang pada sore hari, mereka berkata sambal menangis bahwa Yusuf telah dimakan serigala sambil menyodorkan baju Yusuf yang telah berlumur darah. Di akhir surat diceritakan Ya'kub dan anak-anaknya bertemu lagi dengan Yusuf setelah Yusuf menjadi seorang penguasa di Mesir.

Surat Yusuf ini memaparkan bagaimana sikap seorang ayah menghadapi anak-anaknya yang nakal dan melanggar ketentuan agama. Meskipun telah berusaha memberikan pendidikan yang baik kepada anak-anak,

8 Ibid. 
sangat mungkin diantara mereka ada yang sulit dikendalikan. Terdapat pelajaran yang bisa diambil dalam peran Ya'kub sebagai seorang ayah :

a. Ya'kub adalah seorang ayah yang penuh kasih sayang kepada anaknya. Ya'kub memanggil Yusuf dengan "ya bunayya” (Yusuf, 12:5), panggilan yang mengisyaratkan kasih sayang dan kemesraan. AlQur'an ternyata mengungkapkan panggilan Ya'kub yang berbeda kepada anak-anaknya. ${ }^{9}$ Jika kepada Yusuf, Ya'kub memanggil dengan "ya bunayya", maka kepada saudara-saudara Yusuf, dia memanggil dengan "ya baniyya" (Yusuf, 12: 87).

b. Ya'kub adalah seorang yang sangat sabar dalam mendidik anaknya meskipun anak telah melakukan sesuatu kesalahan yang sangat besar. Kesabaran Nabi Ya'kub diungkapkan dengan ucapannya "Sabar itu indah", ungkapan ini dua kali diucapkan Ya'kub;

1) ketika saudara Yusuf datang kepadanya hanya dengan membawa baju Yusuf yang berlumuran darah yang diakui mereka bahwa Yusuf dimakan serigala padahal mereka telah membuang Yusuf ke dalam sumur (Yusuf, 12:18).

2) ketika saudara- saudara Yusuf tidak mampu membawa Bunyamin kembali kepadanya (Yusuf, 12: 83).

c. Ya'kub adalah seorang ayah yang mampu mengendalikan kemarahannya dalam menghadapi perilaku anak-anaknya, (ayat alquran) dan yakub berpaling dari anak-anaknya seraya berkata "Betapa aku sangat berduka terhadap Yusuf". Kedua matanya menjadi putih karena sedih dan adalah seorang yang menahan amarah (Yusuf, 12:84).

Al-Qur'an memberi pujian untuk Ya'kub Kazhim yaitu orang yang mampu mengendalikan marah. Ketika anak-anaknya melaporkan bahwa mereka tidak bisa membawa Bunyamin pulang karena tertahan di Mesir, Ya'kub mampu mengendalikan diri dan perasaannya. Ia berpaling dan meninggal- kan anak-anaknya untuk menyendiri dan mengungkapkan kepada Allah kesedihan dan

${ }^{9}$ (Rahmi / Kafa'ah: Jurnal Ilmiah Kajian Gender, Vol.V No.2 Tahun 2015) 
kekecewaannya, bukan karena benci kepada mereka, tetapi karena membutuhkan keadaan tenang yang tenang.

\section{Beruntungnya Orang Tua Yang Memiliki Anak Sholeh}

Demi mendesak pembinaan dan pendidikan anak agar bisa menjadi anak yang sholeh, Allah swt. langsung membebankan tanggung jawab kepada orang tua. Allah berfirman, "Hai orang-orang yang beriman peliharalah dirimu dan keluargamu dari apa yang bahan bakarnya manusia dan batu." (QS. At-Tahrim: $6)$.

Rasulullah saw memikul tanggung jawab pendidikan anak kepada orang tua. Abdullah ibn Umar Ra berkata "didiklah anakmu, karena sebaliknya akan dimintai pertanggung jawaban tentang pendidikan dan yang telah disutujui diberikang pertanggungan. Dan dia juga akan meminta bantuanmu dan juga ketaatannya untuk dirimu."(Tuhfah al- Maudud, h. 123.)

Ada dua kata kunci dalam islam yang menyatakan bahwa manusia ditempatkan sebagai hamba dan khlifah dalam transisi. Dua amanat ini dipikul oleh manusia sepanjang perjalanan. Ayah punya tugas untuk membimbing sejak kecil, agar menjadi hamba dan khalifah yang baik. Allah subhanahu wata'ala sudah mewanti-wanti hal ini agar ayah mempersiapkan anakanak agar betul menjadi hamba sekaligus khalifah yang baik. Hamba dan khalifah yang baik itu bagaimana? Jawabannya adalah dalam ayat sebagai berikut:

"Dan pergilah takut kepada Allah orang-orang yang seandainya pergi dibelakang mereka anak-anak yang lemah, yang mereka khawatir terhadap kesejahteraan mereka. Oleh sebab itu barulah mereka bertakwa kepada Allah dan haruslam mereka meminta prkataan yang benar." (QS. An-Nisa: 9)

Rasa takut kepada Allah subhanahu watala mengundang yang mestinya dipunyai seorang ayah, karena dengan punya rasa takut akan memelihara anakanak dengan serius. Ketakutan itu dipenuhi dengan takwa kepada Allah dan berucap benar. Takwa berarti melaksanakan perintah Allah dan menjauhi laranganNya.

Pendidik pertama dan yang paling utama adalah orang tua sendiri. Mereka berdua yang bertanggung jawab penuh atas kemajuan perkembangan anak kandungnya, karena sukses tidaknya anak sangat tergantung pengasuhan, perhatian, dan pendidikannya. Kesuksesan anak kandung adalah cerminan atas kesuksesan orang tua juga. Allah berfirman: 
"Hai orang-orang beriman perihalahlah dirimu dan keluarga darinapi neraka yang bahan bakarnya terbuat dari manusia dan batu, dan penjaganya adalah malaikat malaikat yang kasar, kesar dan tidak mendurhakai Allah terhadap apa yang diperintahkannya kepada mereka dan selalu mengerjakan apa yang diperintahkan." 10

\section{Realita Seorang Ayah Zaman Ini}

Sebagian ayah beranggapan bahwa mendidik anak-anak adalah tanggung jawab ibu saja, tidak ada kewajiban baginya, kecuali menajmin kebutuhan marteri bagi istri dan anak-anaknya. Karena itu kita dapati seorang ayah menghabiskan sebgaian besar waktunya diluar rumah untuk bekerja, atau bersama rekanrekannya. Jika dia pulang kerumahnya, ia hanya duduk sendirian dikamar sembari memperingatkan istrinya yang membiarkan anak-anak mengganggu ketenangannya saat merenung dan bermimpi saat tidur.

Sebagian ayah berlalu seperti orang bisu, tidak ada waktu untuk berdialog bercanda dan bermain dengan anak-anaknya. Padahal dalam alquran dialog antara ayah dan anaknya sebnyak empat belas kali. Sedangkan dialog ibu dan anaknya sebanyak dua kali dan dialog dengan keduanya sebanyak sekali.. ternyata alquran ingin memberikan pelajaran bahwa untuk melahirkan generasi istimewa harus memenuhi komposisi diatas. Syeikh Khalid Ahmad Asy syantud berkata sebenarya, seorang ayah memiliki peran dalam pedmdidikan anak yang secara sederhana dimulai sejak dua atau tiga dari masa kelahiran anak.

Perannya akan semangkin meningkat seiring pertumbuhananak, sehingga beranjak dewasa, lebbih lebih ketika istri sibuk dengan kelahiran anak berikutnya. Pada saat seperti itu, anak yang sudah disapih harus didekatkan dengan ayahnya secara konsisten utnuk mengurangi kecemburuannya terhadap adiknya yang baru lahir yang akan mengambil alih kasih saying ibunya. Anak milai mengenal suara ayahnya sejak tiga hulan pertama.

Pada tahun kedua, seorng ayah dianjurkan untuk bermain dengan anaknya yang sudah bisa berjalan. Ia harus bisa bermain dengan permainan sang anak dan dengan cara cara yang menggembirakan dan mebuat ia puas. Ketika anak mencapai usia 4 tahun, sang ayah sebaiknya mengajak anaknya kemasjid, pasar, atau berkunjung ke kerabat atau temannya. Mengajak anak agar

\footnotetext{
10 Tim penerjemah departemen agama RI, Alquran dan terjemahannya (Jakarta: CV. J-Art, 2004) h. 560
} 
mendampingo ayah akan menumbuhkan jiwa social yang baik, dan menanamkan nilai-nilai luhur pada anak. (Daur bait fii tarbiyati Thiflil Muslim).

\section{a. Nasehat Untukmu Ayah}

Seorang ayah hendaknya memberikan pelajaran kepada anaknya bisa kapan saja. Bisa saat dalam perjalanan, dimobil, dan tidak terfokus di dalam rumah. Terutama mengajari anak-anaknya perkara agama. Maka menjadi suatu keharusan bagi seorang ayah untuk mengetahui permasalan agama, faham halal dan haram, memahami berbagai kiat mendidik, perinsif-perinsif akhlah dan kaedah-kaedah syariat. Apabila dia mengetahui hal tersebut, maka dia harus mempelajari persoalan agama.

Hal ini dimaksudkan agar ayah dapat beribadah kepada Allah berdasarka ilu dan pemahaman yang benar. Ketika anak masi kecil, mereka tidak tahu mana yang benar mana yang salah, mana yang baik mana yang buruk. Yang ada dalam dirirnya adalah perasaan senang yang mendorongnya untuk mengetahui orang yang mengarahkan dan membimbingannya hingga anak hidup dalam pengaruh orang yang membimbingnnya. Apabila pengaruh pembimbing dan pengarah perilakunya tidak ada, maka anak akan tumbuh dalam kebingunan, motivasi, dan keperibadian yang lemah.

Syeikh Dr. shalih bin fauzan menjelaskan bahwa ayah sebagai penanggung jawab terbesar dlam rumah tanggaberkewajiban mendidik keluarga serta putra-putrinya untuk mentaati Allah swt.. Ia berkewajiban untuk menumbuh kembangkan semua anggota keluarganya berdasarkan asas ketaatan kepada Allah swt.. Dan senantiasia mengirinya dengan doa. Sebab doa doa yang dilantunkan oleh para nabi adalah doa khusus yang dikirimkan untuk kebaikan anak-anak dan keturunannya. (taujihat al muhimmah lisyababil ummah, h,15-16).

\section{Ayah Keringatmu Beraroma Surga}

Ada peran yang cukup fital yang dimiliki seorang ayah dalam keluarganya. Peran yang tak kalah menantang disbanding peran seorang ibu. Peran yang sarat tekanan yang harus dihadapi degantenaga, fikiran, dan mental. Bahkan pepatah begitu hebatnya menggambarkan peran ini dalam kat-kata: "peras peringat banting tulang."Mencari nafkah itulah peran yang dimiliki seorang ayah. Sebagai kepala keluarga, seorang ayah bertangung jawab untuk menafkahi 
keluarganya. Bahkan sebelum menjadi seorang ayah, seorang suami berkewajinam menafkahi istrinya.

Seperti itulah peran utama seorang kepala keluarga. Lalu adakah hubungannya dengan surga?, jawabannya ada! Pda keringat seorang ayah, ada pengampunan yang Allah swt. janjikan. Rasulullah bersabda.

"sesunguhnya diantara dosa dosa itu, ada yang tidak dpat terhapus dengan puasa dan salat. Maka para sahabat bertanya, apakah yang dapat menghapusnya ya Rasulullah? Beliau menajwab, bersusah payah dalam mencari nafkah." (HR, Bukhari)

Surga sudah selayaknya menjadi balasan bagi seorang ayah, yang selalu mengahadapi tekanan-tekanan dari berbagai penjuruh ketika mencari nafkah. Ada kecintaan Allah pada tekanan-tekanan itu.

Rasulullah bersabda:"siapa saja dimalam hari bersusah payah dalam mencari rezeki yang halal, malam itu ia diampuni." (HR ibnu Asakir dari Anas), atau dalam hasdis lain, "siapa saja pada sore hari bersusah payah dalam berkerja, maka sore itu ia diampuni." (HR thabrani dan ibu abbas). Rasulullah juga bersabda. " sesungguhnya Allah suka melihat hambahnya bersusah payah dalam mencarii rezeki yang halal" (HR dailami).

Bahkan, bekerja keras mencari nafkan ini termasuk bagian dari jihad. "barangsiapa yang bekerja keras mencari nagkah untuk keluarganya, maka sama dengan pejuang dijalan Allah." (HR ahmad). Begitulah menjadi orang tua berarti kita siap berjihad. Seorang ibu berjihad dalam rumahnya membesarkan anakanaknya, seorang berjihad dimedan usahanya. Ayah, engkau terhubung dengan surge melalui kerja kerasmu. Maka bergembiralah!!!

\section{Simpulan}

Salah satu kunci pembuka untuk akrab dan dekat dengan anak adalah sifat lembut. Orang tua yang membiasakan kelembutan dalam mendidik anak, maka anak in syaa Allah swt. akan bertutur kata lembut, bersikap hati-hati dan tidak berperangai keras lagi kasar. Rasulullah saw telah mencontohkan kepada kita bagaimana bergaul dan berinteraksi dengan anak kecil yang didasari rasa kasih sayang yang tulus. Anas menegaskan:

"Rasulullah saw. adalah yang paling penyayang terhadap anak dan keluarga". (hadits shahih riwayat Ibnu Asakir, shohih al-jami’ no. 40). Ibnu Abbas menuturkan, "Rasulullah saw mengunjungi kaum anshar lalu memberi salam 
kepada anak-anak mereka serta membelai kepala mereka.”(HR. an-Nasai dishahihkan al-Albani dalam shahih al-Jami' no. 4947).

Kedekatan beliau dengan anak-anak tidak menghalangi untuk menyampaikan nasihat dan bimbingan ketika anak-anak melakukan kesalahan. Umar bin Abi salamah bercerita, "dulu aku adalah bocah yang berada dalam pengasuhan Rasulullah saw”, suatu ketika tangan ku berseliweran diatas nampan, maka Rasulullah saw bersabda kepadaku,

$$
\text { يا غلام سم الله وكل بيمينك وكل مما يليك }
$$

“Ananda bacalah bismillah dan makanlah dengan tangan kananmu dan apa yang ada disekitarmu." (HR. Bukhari dan Muslim), maka sangat indah gambaran Islam tentang kasih sayang seorang ayah yang tulus kepada anaknya.

\section{Pustaka Acuan}

Al-Qur'an

Tim penyusun kamus besar basaha Indonesia, Jakarta: Balai Pustaka, 2005.

Jhon M. Echols dan hasan shdily, kamus Indonesia inggris, Jakarta: PT. Gramedia, 1992.

Zakiyah Drajat, Islam Untuk Disiplin Ilmu Pendidikan, Jakarta: Bulan Bintang, 1987.

Ahmad Tafsir, Ilmu Pendidikan dalam Persfektif Islam, Bandung: Remaja Rosdakarya: 1992.

Kementrian Agama RI, Al-Qur'an dan Tafsirnya. Edisi yang disempurnakan Jakarta: Lentera Abadi, 2010.

Hery Noer Aly, MA, Dan H. Munzier S, MA. Watak Pendidikan Islam Jakarta: Friska Agung Insani, 2003.

Rahmi / Kafa'ah: Jurnal Ilmiah Kajian Gender Vol.V No.2 Tahun 2015.

Tim penerjemah departemen agama RI, Alquran dan terjemahannya Jakarta: CV. J-Art, 2004. 